\title{
Integracyjna działalność Kościoła warmińskiego \\ w pierwszych latach \\ po II wojnie światowej
}

\section{STANISŁAW ACHREMCZYK}

Ośrodek Badań Naukowych im. Wojciecha Kętrzyńskiego w Olsztynie

\section{ROCZNIK}

\section{ZIEM}

\section{ZACHODNICH}

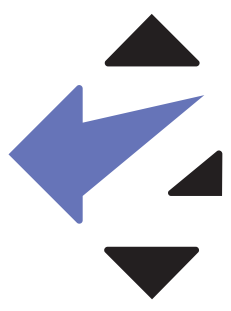


W roku 1945 południowe Prusy Wschodnie, zwane dziś Warmią i Mazurami, znalazły się we władaniu Polski. Ziemie te w całości należały do diecezji warmińskiej, która przed wojną liczyła 36999 km kw., a po wojnie tylko 24344 km kw. W 1944 r. składała się z 19 dekanatów, 194 parafii, posługę pełniło 368 kapłanów diecezjalnych, 33 zakonnych, a mieszkało w niej 373480 katolików ${ }^{1}$. Po roku 1945 nastąpiły ogromne zmiany, a liczba katolików zaczęła szybko wzrastać. Statystyki kościelne podają, że w 1948 r. na 680 tys. mieszkańców diecezji, 590 tys. stanowili katolicy. Zmieniły się radykalnie stosunki wyznaniowe. Katolicy nie stanowili już diaspory otoczonej ewangelicką większością. Zarówno na historycznej Warmii, jak i na Mazurach byli w większości.

Po zakończeniu działań wojennych Prusy Wschodnie były terenem nie tylko bardzo zniszczonym, lecz przede wszystkim wyludnionym. W gruzach leżały centra prawie wszystkich miast, wsie opuszczone, ziemie nie uprawione. W prowincji, w której w 1939 r. mieszkało około 2,5 mln mieszkańców, pozostało około 400 tys., z czego połowa w utworzonym przez Rosjan obwodzie kaliningradzkim. Ofiary ludności cywilnej można było liczyć w tysiącach. Przyjmuje się, że w czasie ewakuacji i ucieczki zginęło blisko 150 tys. osób. Niektórzy z historyków przyjmują, że życie straciło 311 tys. osób samej tylko ludności cywilnej². Po ustaniu działań wojennych, a trwały one do pierwszych dni maja 1945 r., zaczęli powracać do domów uciekinierzy, których wojska radzieckie dopadły w okolicach Gdańska, Wejherowa czy Pomorza Zachodniego. Stosunkowo szybko zaludniła się południowa Warmia, gdyż ludność tutejsza nie usłuchała do końca rozkazu o ewakuacji. Ludność niemiecką zaczęto koszarować w osobnych dzielnicach, a także obozach. W obozie przejściowym w Iławie do sierpnia 1945 r. miało przebywać 13 tys. ludzi, nie tylko jeńców wojennych, ale i cywilów. Prowincja pokryła się siecią obozów NKWD, z których deportowano ludność do Związku Radzieckiego. Trudno określić liczbę mieszkańców Prus Wschodnich wywiezionych w głąb Rosji, przyjmuje się, iż kilkadziesiąt tysięcy zostało wywiezionych, a ponad 30 tys. nigdy nie powróciło do swoich stron rodzinnych. Ci co pozostali, szykowali się do wyjazdu na Zachód. Władze polskie popierały wysiedlanie. Już w sierpniu 1945 r. z Olsztyna miało wyjechać około 1500 osób narodowości niemieckiej, a z powiatu nidzickiego blisko 1700 osób, pojedyncze osoby opuszczały też bardzo zniszczony powiat braniewski. Oficjalne statystyki odnotowały wysiedlenie do końca roku 1945 ponad 60 tys. osób, natomiast najnowsze ustalenia podwyższają tę liczbę do prawie stu tysięcy Niemców³. Od roku 1946 akcja wysiedlania ludności niemieckiej nabrała rozmachu. Do końca 1950 r. zorganizowanymi transportami tylko z ówczesnego województwa olsztyńskiego wysiedlono

1 A. Kopiczko, Kościół warmiński a polityka wyznaniowa po II wojnie światowej, Olsztyn 1996, s. 12.

2 A. Sakson, Od Kłajpedy do Olsztyna. Współcześni mieszkańcy byłych Prus Wschodnich. Kraj Kłajpedzki, Obwód Kaliningradzki, Warmia i Mazury, Poznań 2011, s. 111; A. Kossert, Ostpreussen. Geschichte und Mythos, München 2005, s. 330. 
72 tys. ludności niemieckiego pochodzenia ${ }^{4}$. Pierwszymi transportami wywożono księży, nauczycieli, lekarzy, inteligencję niemiecką, a także ludzi starych, kobiety i dzieci. Władze polskie uznały, że problem ludności niemieckiej na obszarze południowych Prus Wschodnich został rozwiązany. Ludność, która pozostała, uznano za nadającą się do repolonizacji. O ile Warmiacy przywiązani do swych gospodarstw pod przymusem milcząco podpisywali dokumenty o przynależności do narodowości polskiej i przyjmowali dowody osobiste, o tyle Mazurzy takim procedurom się nie poddawali. Mazurzy znaleźli się w trudniejszym położeniu niż Warmiacy. Rok 1945 przyniósł na Mazurach rozpad Kościoła unijnego, opiekę nad ludnością mazurską przejął Kościół ewangelicko-augsburski. W diecezji mazurskiej w roku 1950 wiernych naliczono około 68500 , parafii 89, duszpasterstwo prowadziło dziewięciu księży i trzech diakonów. Na Mazurach pojawił się Kościół metodystyczny oraz inne odłamy protestantyzmu. Ta wielość protestanckich wyznań, dążących do pozyskania ludności mazurskiej, wprowadziła Mazurów w dezorientację i zagubienie. Świątynie nie miały gospodarzy, opuszczone niszczały albo zajmowane były przez polskich osadników.

Miejsce ludności niemieckiej, warmińskiej i mazurskiej zajęła ludność polska przybyła z Mazowsza, Podlasia, Wielkopolski, Małopolski, Pomorza i z polskich Kresów Wschodnich. Jeszcze toczyły się walki, linia frontu zatrzymała się pod Braniewem, a już na teren Prus Wschodnich zaczęli przybywać polscy osadnicy. Jedni przybywali, by zorganizować polską administrację, drudzy, aby ochraniać zakłady przemysłowe, jeszcze inni szukali nowego domu, a byli też i tacy, którzy przyjeżdżali na zwykły szaber. Po przejściu frontu spontanicznie napłynęła ludność z województw warszawskiego, białostockiego, łomżyńskiego i Kurpiowszczyzny ${ }^{5}$. Na teren powiatów ełckiego, gołdapskiego, giżyckiego przybywali mieszkańcy sąsiednich gmin powiatu szczuczyńskiego, augustowskiego i suwalskiego. Niektóre wsie zasiedlili sami swoi, np. do wsi Stare Cimochy przyjechali mieszkańcy wsi Rutki w pobliżu Augustowa. Z okolic Myszyńca, Przasnysza, Mławy udawano się do przygranicznych powiatów mazurskich. W pierwszym okresie osadnictwa do maja 1945 r. dominował żywioł potęgowany plagą szabrownictwa. Nie wszyscy jednak przybywali na teren Prus Wschodnich z zamiarem wzbogacenia się, wielu przyjeżdżało, by osiąść tu na stałe. Jechali z dziećmi, niewielkim dobytkiem mieszczącym się na wozie, ze świętymi obrazami. Prości ludzie z Suwalszczyzny, Łomżyńskiego, Kurpiowszczyzny, Mazowsza odbudowywali domy, odgruzowywali ulice, orali pola, żniwowali, pozostawieni sami sobie wiedli normalne życie. Ze zrujnowanej Warszawy napłynęli jej mieszkańcy

4 A. Sakson, op. cit., s. 226; S. Żyromski, Przesiedlenia ludności niemieckiej z województw olsztyńskiego poza granice Polski w latach 1945-1950, „Komunikaty Mazursko-Warmińskie” 1959, nr 3, s. 400; M. Płotek, Losy sierot narodowości niemieckiej z terenu Warmii i Mazur po zakończeniu II wojny światowej, „Komunikaty Mazursko-Warmińskie” 2005, nr 3, s. 349-362.

5 M. Nowotka, Przemiany ludnościowe na pograniczu mazursko-kurpiowskim po II wojnie światowej na przykładzie gminy Rozogi, [w:] Migracja ludności na pograniczu mazursko-kurpiowskim w XIX i XX wieku, red. J. Gołota, Ostrołęka-Olsztyn 2008, s. 133-144; Z. Kudrzycki, Przemiany społeczno-polityczne na pograniczu mazursko-kurpiowskim po 1945, [w:] Migracja ludności na pograniczu mazursko-kurpiowskim..., s. 72-78; Z. Kudrzycki, Dzieje Rozóg, Toruń 2003, s. 136-142. 
i to w liczbie ponad 8 tys. Przyjeżdżała ludność z polskich Kresów Wschodnich. Zostawiała swoje domy, gospodarstwa, małą ojczyznę, by towarowym pociągiem wyruszyć do dalekiego nieznanego kraju. Uciekali od Stalina, a tymczasem Stalin na portretach witał ich na polskich kolejowych dworcach. Przyjeżdżali Polacy z Grodzieńszczyzny, Podola, Wileńszczyzny, Brasławszczyzny, z tragicznego Wołynia i zesłańcy z syberyjskich łagrów. Niesłusznie nazwano ich repatriantami. Niełatwe były rozstania $\mathrm{z}$ ojczystą ziemią. $\mathrm{W}$ takich chwilach przełomu, gdy smutek mieszał się z nadzieją, powstawały wiersze pisane przez prostych ludzi. Nieznany poeta, opuszczając Wilno, pisał: „Żegnaj Wilno ukochane, droższe ponad cały świat... Żegnaj Matko Ostrobramska, W drodze otul płaszczem swym”. Dzisiejsza mieszkanka Kętrzyna tak wspomina wyjazd:

ojca aresztowali sowieci w 1944 roku i skazali na 14 lat zesłania w Workucie, a my 17 grudnia 1945 wyjechaliśmy z Turmont trzecim transportem. Dookoła zima, głęboki śnieg, mróz. W dzień Wigilii znaleźliśmy się w Olsztynie. Ksiądz Lachowicz chodził po wszystkich wagonach, dzielił się opłatkiem, składał życzenia na nowym miejscu życia. Z Olsztyna ludzie zostali skierowani do Bartoszyc, Lidzbarka, Kętrzyna i Korsz. I tak 1 stycznia 1946 roku znaleźliśmy się w Rastenburgu. Ksiądz Lachowicz wysiadł w Korszach. Zatrzymaliśmy się przy rampie. Było pusto, zimno, głucho. Czekaliśmy ranka. Modliliśmy [się], płakaliśmy, bo wokół rozciągały się ruiny, obce miasto, rosyjscy żołnierze`.

Do roku 1950 ponad 130 tys. Kresowiaków przyjechało na Warmię i Mazury8 ${ }^{8}$. W 1947 r. pojawiła się ludność ukraińska. Trwała wielka wędrówka ludzi, jedni przyjeżdżali, drudzy wyjeżdżali, trwało poczucie tymczasowości i wiara, że wnet powrócą na Wschód do siebie.

Zasiedlenie Warmii i Mazur (a w 1950 r. tylko w ówczesnym województwie olsztyńskim mieszkało 689 tys. osób) przez różne grupy przesiedleńców, pochodzących z różnych stron Rzeczypospolitej, różniących się od siebie pod względem kulturowym i cywilizacyjnym systemem wartości, powodowało ogromne trudności w adaptacji do nowego środowiska kulturowego. Pierwszych osadników wiele różniło wyznanie religijne, obyczaje, zwyczaje, kultura osobista, słownictwo. Uwidaczniało się to najbardziej w czasie świąt kościelnych, kiedy każdy po swojemu obchodził je we własnym kręgu. Zwornikiem pozostawał Kościół. Ludzie osiedlali się tam, gdzie zobaczyli wieżę kościoła albo dowiedzieli się, że jest już we wsi ksiądz. Oni przywieźli ze sobą kult Matki Boskiej Ostrobramskiej. Do Butryn trafił relikwiarz św. Antoniego z Korca, do Zielonki Pasłęckiej z Wołynia przywieziono obraz Chrystusa Króla Boleści. Przybyłe osoby księża podnosili na duchu dobrym słowem 
i wspólną modlitwą. Ksiądz Józef Kącki, który w styczniu 1946 r. z Krakowa jechał na północ, widział gruzy Warszawy, Olsztyna, nadwyrężone wojną wsie i zatrzymał się w Ełku. Poznawał to miasto wypalonych domów, jak również mieszkańców i ich losy. We wspomnieniach napisal:

jednym spalono domy w czasie działań wojennych, drugim za przynależność do AK. Inni wyrzuceni ze swoich domów jako repatrianci nie podpisali obywatelstwa radzieckiego. Jeszcze inni przyjechali, żeby się ukryć przed pościgiem za przynależność do AK. Wyrzuceni z własnych domów, ojcowizny... Wiedzieli, co to łapanki, wywózki, głód na zesłaniu, brak chleba, księdza. Byli ludzie o różnych przyzwyczajeniach kulturowych i nawykach. Przywiezieni z daleka, przyzwyczajeni do swych miejscowości, które musieli opuścić, wylęknieni, biedni. Na co dzień słyszeli, że mogą powrócić tu Niemcy. Podobni do wyrzuconego pieska, czekającego na strawę, szukającego nowego pana. Jakże zacni, dobrzy, na wskroś religijni... chcieli żyć. Szukali oparcia9.

Tego oparcia szukali w Kościele. Tymczasem wojna dotknęła Kościół warmiński tak samo jak całą wschodniopruską prowincję. Kościoły były spustoszone albo zburzone, wielu księży zginęło, część ewakuowała się, a pozostałych po roku 1945 wysiedliły władze polskie. Z księży warmińskich życie straciło 130 osób, 22 zostało rozstrzelanych przez Armię Czerwoną. Gehennę przeszły siostry zakonne. W pierwszych miesiącach 1945 r. zmarło lub zginęło pięciu kanoników warmińskich. Księdza Władysława Świtalskiego zastrzelił żołnierz radziecki, na skutek pobicia zmarł ks. Józef Steinki, zmarli także kanonicy Andrzej Hinzmann, Antoni Krause, Franciszek Sander, Brunon Gross, Franciszek Heyduschka, niektórzy opuścili Frombork ${ }^{10}$. Los swych kapłanów podzielił biskup Maksymilian Kaller. Opuszczając w lutym 1945 r. Frombork, Kaller powierzył rządy nad diecezją wikariuszowi generalnemu ks. Alojzemu Marquardtowi. Ten jednak zaraz po wywiezieniu przez gestapo biskupa znalazł się w więzieniu radzieckim. W połowie czerwca $1945 \mathrm{r}$. Marquardt uwolniony z więzienia pojawił się $\mathrm{w}$ Olsztynie. Wraz z sekretarzem kapituły katedralnej, ks. Janem Parschau, zatrzymali się u ks. Jana Hanowskiego. Ksiądz Marquardt podjął decyzję zorganizowania w Olsztynie kurii diecezjalnej ${ }^{11}$. Wydawało się, że wykazując lojalność wobec władz polskich, choć nie znał języka polskiego, otrzyma swobodę działania i pozostanie w Olsztynie. Ksiądz Marquardt miał nadzieję, że „nowa władza użyczy Kościołowi pożądane swobody, aby i Kościół ze swej strony mógł przyczynić się do ustalenia porządku i podniesienia poziomu moralnego naro$\mathrm{du}^{\prime \prime 2}$. Niestety, płonne okazały się te nadzieje. Ksiądz Jan Parschau, z którym przybył

10 J. Wojtkowski, Dzieje kapituły warmińskiej 1772-1945, „Studia Warmińskie”, t. XXXII (1995), s. 88-90; A. Kopiczko, Kościół warmiński..., s. 13.

11 A. Kopiczko, Kościół warmiński..., s. 13-14; J. Obłąk, Z powojennych dziejów diecezji warmińskiej. Luty-wrzesień 1945, „Polonia Sacra”, 8 (1956), z. 3-4, s. 401-403. 
do Olsztyna, został już w sierpniu 1945 r. aresztowany po odprawieniu mszy św. w kościele w Dajtkach. Wywieziono go w głąb Związku Radzieckiego. Wolność odzyskał w 1956 r. W więzieniu znalazł się też franciszkanin Sebastian Pietrek. Przetrzymywano go w obozie w Elblągu, a gdy go z obozu wypuszczono, wyjechał na Śląsk ${ }^{13}$. Księża niemieccy zostali zmuszeni do opuszczania diecezji warmińskiej. Władze dążyły, by byli oni zastępowani przez polskich kapłanów. Przybywało coraz więcej księży z ziem polskich, pracę $\mathrm{w}$ diecezji podjęli franciszkanie. Tymczasem władze nakazały, żeby ks. Marquardt opuścił Polskę. Natomiast Urząd Pełnomocnika Rządu RP na Okręg Mazurski pismem nakazywał mu przeprowadzenie następujących zmian: parafie powierzać księżom przybyłym z Polski, niemieckie napisy w kościołach zastępować polskimi, w każdej parafii organistą powinien być Polak, Ewangelię czytać po polsku, a w miejscowościach, gdzie przebywa ludność niemiecka, także w języku niemieckim, podczas nabożeństw należy śpiewać pieśni polskie, po każdej mszy św. odprawionej w niedzielę, święta kościelne i narodowe należało odmówić modlitwę za ojczyznę oraz zaśpiewać pierwszą zwrotkę pieśni Boże, coś Polskę $e^{14}$. Ksiądz Marquardt zdążył przesłać do Rzymu relacje o stanie diecezji. W niej informował, że biskupa Kallera wywiozło z Warmii gestapo, że kościelna administracja jest obecnie nie we Fromborku, lecz w Olsztynie, diecezja jest zniszczona, a wierni cierpią biedę. Pod koniec lipca (27 lipca) 1945 r. władze nakazały mu opuścić Olsztyn i diecezję. Opuszczając diecezję, postanowił, by wikariuszem generalnym został ks. Jan Hanowski. Do niego też w pierwszych dniach sierpnia 1945 r. przybył biskup Kaller. Kaller, który znał język polski, zabrał się za reorganizację diecezji ${ }^{15}$. Swoim najbliższym współpracownikiem mianował ks. Franciszka Borowca. Biskup planował przeniesienie rezydencji biskupiej i seminarium duchownego z Fromborka do Olsztyna, wprowadzenie polskich księży do kapituły warmińskiej. Polski kapłan miał zostać prepozytem kapituły katedralnej, a czterech polskich księży miało zasiąść w kapitule. Notariat i seminarium duchowne mieli objąć Polacy. W pracy duszpasterskiej biskup Kaller pragnął łagodzić antagonizmy narodowościowe między Polakami a Niemcami. Dla polskich władz pojawienie się Kallera w Olsztynie było niepożądane, nie otrzymał on bowiem polskiego obywatelstwa i został zmuszony do wyjazdu z Olsztyna, a także na ręce prymasa Augusta Hlonda złożył rezygnację z rządów nad diecezją będącą w granicach Polski ${ }^{16}$. Prymas Hlond 14 sierpnia

15 A. Ornatek, Biskup Maksymilian Kaller - wierność pasterskiemu powołaniu, „Warmińskie Wiadomości Archidiecezjalne” 1993, nr 8, s. 87-96; J. Chłosta, Jeszcze o biskupie Maksymilianie Kallerze „Warmińskie Wiadomości Archidiecezjalne" 1993, nr 10, s. 126-133; A. Ornatek, W poszukiwaniu prawdy o biskupie Maksymilianie Kallerze, „Warmińskie Wiadomości Archidiecezjalne” 1994, nr 10, s. 133-138; J. Chłosta, Maksymilian Kaller biskup warmiński w latach 1930-1947, [w:] Poczet biskupów warmińskich, red. S. Achremczyk, Olsztyn 2008, s. 445; J. Obłak, A. Kopiczko, Historia diecezji i archidiecezji warmińskiej, Olsztyn 2010, s. 138; A. Kopiczko, Kościół warmiński..., s. 16; B. Schwark, Ihr Name lebt. Ermländische Priester in Leben, Leid und Tod, Osnabrück 1958, s. 18-19. 
1945 r. mianował administratorem apostolskim diecezji warmińskiej ks. dr. Teodora Benscha $^{17}$. We wrześniu $1945 \mathrm{r}$. ks. Bensch pojawił się w Olsztynie, a 14 października dokonał ingresu do kościoła św. Jakuba. W uroczystej procesji przeszedł od kościoła Najświętszego Serca Pana Jezusa (dalej: NSPJ) do kościoła św. Jakuba. W centrum miasta wzniesiono bramę triumfalną, „przemówienie powitalne wygłosił prezydent miasta pan Latosiński, wręczając administratorowi apostolskiemu symboliczny chleb i sól"18. Przy drzwiach dzisiejszej katedry powitał administratora ks. Jan Hanowski. W procesji i nabożeństwie wzięli udział Polacy, Niemcy i liczni Warmiacy przyznający się do polskości. Przed ks. Benschem stanął ogrom pracy, niemal wszystko trzeba było zaczynać od nowa. W dokumencie Ligi Katolickiej z Ameryki, która pomagała diecezji warmińskiej, odnotowano w kwietniu 1948 r.:

Diecezja warmińska ongiś pełna życia religijnego została wskutek ostatnich działań wojennych w straszliwy sposób zniszczona. J.E. ks. dr Teodor Bensch zastał w chwili objęcia diecezji w dniu 1 września 1945 r. kompletny chaos, który ilustrują następujące dane: z 170 kościołów na pozostałym terenie diecezji warmińskiej 14 uległo całkowitemu zniszczeniu, inne częściowo zniszczone, a prawie wszystkie wewnątrz zostały ograbione i zdewastowane. Z ogólnej liczby duchowieństwa - 438. Zmarło śmiercią tragiczną i naturalną wskutek działań wojennych 86, wywieziono około 38, pewna liczba wyjechała tak, że w diecezji zostało blisko 50 księży. Klasztory uległy zniszczeniu. Najbardziej ucierpiały klasztory żeńskie, wiele sióstr zabito, zhańbiono i wywieziono. Podobny los spotkał wiernych ${ }^{19}$.

Kościół był potrzebny, normalizował powojenne życie, wnosił element stabilizacji i pewności, łagodził antagonizmy dzielnicowe, łączył ludzi, a nie dzielił, wreszcie wspierał potrzebujących pomocy materialnej. Nim napłynęli wraz z osadnikami polscy księża, posługę duszpasterską starali się wypełniać księża warmińscy, którzy nie poddali się rozkazowi ewakuacji. W Olsztynie pozostał ks. Jan Hanowski, który uratował przed spaleniem olsztyńskie świątynie. W niedzielę wielkanocną roku 1945 właśnie on odprawiał mszę św. w kościele św. Jakuba. Maria Zientara Malewska, która uczestniczyła w nabożeństwie, zapamiętała:

zebrała się gromadka Polaków po jednej stronie i katolików niemieckich po drugiej. Śpiewaliśmy pieśni wielkanocne. Po nabożeństwie ktoś zaintonował Boże, coś Polskę. Co to był za śpiew, stale się rwał przeplatany łkaniem. Polacy płakali ze wzruszenia, a Niemcy z przygnębienia i żalu²0.

17 Ibidem, s. 53, 56; J. Pietrzak, Działalność kardynała Hlonda jako wysłannika papieskiego na Ziemiach Odzyskanych w 1945 r., „Nasza Przeszłość” 1974, t. 42, s. 213; J. Obłąk, A. Kopiczko, op. cit., s. 140-141.

18 B. Łukaszewicz, Raptularz miejski, Olsztyn 1945-2005, Olsztyn 2006, s. 28.

19 A. Kopiczko, Kościół warmiński..., s. 15. 
Ksiądz Hanowski ${ }^{21}$ odegrał niezwykłą rolę, otaczając opieką duszpasterską pozostałych Warmiaków, a także tych, którzy po roku 1945 napłynęli do Olsztyna. Przyjmuje się, iż 1 września 1945 r. pozostało w diecezji 97 kapłanów. Polskie władze nakazywały powierzanie parafii księżom przybyłym z Polski, usuwanie w kościołach napisów w języku niemieckim, czytanie Ewangelii w języku polskim, a w miejscowościach, gdzie ludność była mieszana, również w języku niemieckim, podczas nabożeństw miano śpiewać polskie pieśni. Kościół stanął wobec ogromnych wyzwań - zorganizować parafie, odbudować świątynie, wyposażyć je w sprzęt liturgiczny, utwierdzić wiernych w przekonaniu, że na nowych ziemiach nie są intruzami i objąć opieką wiernych mieszkających tu od wieków. Wracali do swych parafii proboszczowie, którzy je opuścili przed wejściem wojsk sowieckich. Proboszcz NSPJ Alfons Wardecki już w styczniu był w Olsztynie ${ }^{22}$. Zastał świątynię spustoszona, plebania spalona, a dom parafialny zamieniony na szpital polowy. Słabo znającemu język polski ks. Wardeckiemu z pomocą przyszli polscy księża, bo i parafia w większości była już z polską ludnością. Wikariuszem w październiku 1945 r. został ks. Stanisław Janusz ${ }^{23}$ pochodzący z diecezji przemyskiej. Krótko był w parafii, gdyż 1 października 1946 r. został administratorem parafii w Łynie, aresztowany przez UB, skazany przez olsztyński Wojewódzki Sąd Rejonowy na karę śmierci (powiązany z Armią Krajową i Zrzeszeniem „Wolność i Niezawisłość”), ułaskawiony przez Bieruta był więziony w Barczewie, Wronkach, Rawiczu, zmarł w więzieniu we Wronkach 27 października 1952 r. Krótko wikariuszem był ks. Wacław Hipsz z diecezji łuckiej. Bliskim współpracownikiem ks. Wardeckiego został ks. Franciszek Skalski $^{24}$, urodzony na Podolu w styczniu 1902 r. Zanim trafił do seminarium duchownego, przez dwa lata studiował na Politechnice Warszawskiej. Seminarium duchowne ukończył w Łucku. Święcenia kapłańskie przyjął w 1926 r. Po święceniach wyjechał do Paryża studiować socjologię i nauki społeczne, a następnie otrzymał stopień doktora socjologii. Po powrocie do Polski został profesorem Seminarium Duchownego w Łucku. Był też wykładowcą i kapelanem Centrum Wyszkolenia Kawalerii w Grudziądzu. Brał udział w kampanii wrześniowej 1939 r., a gdy jego pułk został rozbity, dostał się do Warszawy. Był uczestnikiem powstania warszawskiego, a także więźniem obozu Stutthof. W Stutthofie był bity i przeszedł tyfus plamisty. Z obozu wyszedł schorowany. Odbudował spaloną plebanię, zorganizował Katolicki Związek Młodzieży Męskiej i Żeńskiej, Sodalicję Mariańską, teatrzyk parafialny. Parafianie przyszli z pomocą przy odbudowie plebanii, zbierając ofiary, a chór parafialny zorganizował nawet w 1948 r. bal karnawałowy, z którego dochód przeznaczono

\footnotetext{
21 J. Chłosta, Niezwykła posługa warmińskiego kapłana, „Studia Warmińskie”, t. 32 (1995), s. 365-377; M. Zientara Malewska, Wspomnienia o księdzu prałacie Janie Hanowskim 1873-1968, „Słowo na Warmii i Mazurach" 1971, nr 20; Warmiacy i Mazurzy w PRL. Wybór dokumentów. Rok 1945..., s. 41, 51.

22 A. Kopiczko, J. Żołnierkiewicz, Dzieje kościoła i parafii Najświętszego Serca Pana Jezusa w Olsztynie 1903-2003, Olsztyn 2004, s. 96-97.

23 Ibidem, s. 102-103.

24 Ibidem, s. 103-104.
} 
na remont organów. Poświęcenie plebanii nastąpiło w marcu 1949 r. Ówczesne „Życie Olsztyńskie" w ten sposób opisało uroczystość:

Wśród licznie zebranej publiczności zauważyliśmy protektora uroczystości administratora apostolskiego ks. dr. Teodora Benscha, dyrektora Izby Skarbowej mgr. Sawickiego, jako prezesa komitetu odbudowy Domu Katolickiego, wiceprezydenta Olsztyna mgr. J. Smoleńskiego, szereg osób zaproszonych na uroczystość oraz większą rzeszę parafian wypełniających salę. Uroczystość zagaił mgr Sawicki, podkreślając znaczenie Domu Katolickiego, który powstał z wysiłku ludzi pracy i winien być ogniskiem myśli i pracy katolickiej - pracy dla dobra Ojczyzny w nowych warunkach nowej rzeczywistości. Gorące oklaski były potwierdzeniem, ze zebrani całkowicie akceptują myśli przewodnie wypowiedziane przez mgr. Sawickiego. Po odśpiewaniu pieśni, a przed aktem poświęcenia, zabrał głos administrator apostolski ks. dr Teodor Bensch. Podkreślił on przeobrażenia w pojęciach etycznych człowieka wieku XIX i XX, zaznaczył też mocno, że zasady katolicyzmu są niezmienne, lecz zrozumienie ich związane jest ze światłym postępem. Przytaczając szereg przykładów, zaznaczył, że praca każdego katolika jest pracą dla zespołu, bo życie katolickie jest życiem w zespole... referat Wiara Ojców wygłosił dr Władysław Gębik, informując zebranych o działalności przedwojennej byłego Związku Polaków w Niemczech i omawiając martyrologię polską. Nawiązał on również do tradycji marca, który był poświęcony Wierze Ojców. Chór pod batutą Mieczysława Kulewskiego wykonał wiele pieśni, z których na szczególną uwagę zasługuje kantata Oto Drzewo Krzyża (piękne solo Dąbrowskiego) oraz wyjątki z Mszy św. Maklakiewicza ${ }^{25}$.

Kresowianin, ksiądz Skalski, wraz z proboszczem rodem z Powiśla, a wykształconym w Braniewie, więc można powiedzieć, że Warmiakiem, ks. Wardeckim, takimi uroczystościami integrowali parafian przybyłych do Olsztyna z różnych stron Polski. Z sowieckich łagrów w 1949 r. przybył do Olsztyna ks. pułkownik Giedymin Pilecki, dziekan kapelanów Armii Krajowej. Aresztowany i osadzony w więzieniu. Wreszcie do Olsztyna przyjechał po czteroletnim pobycie w Workucie ks. Jan Romejko ${ }^{26}$. Romejko, urodzony w 1901 r. w Pokrzyżach w powiecie wileńsko-trockim, a ochrzczony w kościele w Niemenczynie, był wychowankiem Niższego Seminarium Duchownego w Wilnie. Studiował na Uniwersytecie Wileńskim, był wikariuszem w Wilnie, prefektem w Grodnie, a od 1934 do 1938 r. proboszczem i prefektem w Dziśnie. W czasie wojny kapelan AK. Nim pojawił się w Olsztynie, był kapelanem szpitala w Dusznikach Zdroju, duszpasterzem w Kętrzynie w parafii św. Katarzyny, gdzie proboszczem był ks. Wacław Radziwon. W styczniu 1950 r. otrzymał nominację na wikariusza w parafii NSPJ, a w październiku tegoż roku został jej proboszczem. 
Na początku roku 1946 do Bartoszyc przyjechał ks. Gracjan Rudnicki, zostając administratorem parafii św. Brunona ${ }^{27}$. Pochodzący z Wołynia ks. Rudnicki ujrzał Bartoszyce zniszczone okrutnie, mieszkańcy zaś zarówno polscy, jak i niemieccy głodowali. Kościół św. Brunona, który przejął, był cały zaśmiecony, bez okien i z dachem $\mathrm{w}$ ruinie. Ksiądz Rudnicki okazał się zaradnym proboszczem, który szybko zyskał sympatię mieszkańców. W krótkim czasie doprowadził do uruchomienia szpitala i uroczyście go poświęcił (1946 r.) i sprawował nad chorymi opiekę duszpasterską. Dostrzegając otaczającą wszędzie biedę, założył parafialny oddział Caritasu. Caritas prowadził też żłobek i dom starców. Odzież, żywność otrzymywali wszyscy proszący, niezależnie od narodowości czy wyznania. Troszcząc się o los biednej młodzieży we wrześniu 1947 r. zorganizował przy plebanii niewielki internat. W internacie uczniowie ze wsi znaleźli miejsce na kwaterę. Jego pomoc młodzieży nie uszła uwagi funkcjonariuszy Urzędu Bezpieczeństwa. Funkcjonariusze i tajni współpracownicy informowali władze o wszelakich poczynaniach księdza. Donosili, że w czasie kazań krytykował rząd i organizacje młodzieżowe. W czasie jednej homilii miał powiedzieć: „robotniku, jeśli jesteś katolikiem i wyznawcą nauki Jezusowej, to nie możesz tolerować tego, nie możesz patrzeć na to obojętnie, bo tam jutro znajdą się twoje dzieci bez twej opieki, w rękach ludzi złych"28. Apelował do rodziców, by ich dzieci nie wstępowały do bezbożnych młodzieżowych organizacji. Wzywano więc ks. Rudnickiego do powiatowego starostwa na rozmowy, pouczano, ostrzegano, grożono, nazwano go wrogiem nowej rzeczywistości ${ }^{29}$. Wkrótce rozwiązano Caritas, zakazano prowadzenia internatu. Poza posługą duszpasterską zaangażował się też w działalność społeczną. Obsługiwał kościoły poza Bartoszycami. Odprawiał nabożeństwa w Galinach w kościele poewangelickim. W sierpniu 1946 r. wierni z Bartoszyc udali się z pielgrzymką na odpust do Galin. A gdy ludność przejęła poewangelicki kościół w Wojciechach, to ks. Rudnicki również dojeżdżał tam z posługą duszpasterską. Ksiądz Rudnicki zyskał tak duże zaufanie w Bartoszycach, iż wybrano go do Powiatowego Komitetu Opieki Społecznej. Na plebanii przy kościele zorganizował internat dla młodzieży uczącej się w szkołach średnich. Już w 1947 r. był nękany przez UB, wielokrotnie przesłuchiwany. Parafia jego liczyła w $1949 \mathrm{r}$. prawie 9 tys. wiernych. Gdy został zmuszony do opuszczenia Bartoszyc, zastąpił go na krótko ks. Giedymin Pilecki, a w roku 1954 ks. Adam Szabunia, Wilnianin. W zachowanych wspomnieniach napisał:

Przyjechałem jako repatriant z Wileńszczyzny w końcu maja 1946 roku. Transport nasz zatrzymano w Lidzbarku Warmińskim. Ówczesny rządca diecezji warmińskiej ks. dr Teodor Bensch proponował do objęcia Nibork, obecnie Nidzica. Był tam jednak jeszcze proboszcz Niemiec... Chciałem osiąść w Bartoszycach przy częściowo zniszczonym kościele św. Jana 
Ewangelisty... wreszcie objąłem Sterławki Wielkie. Były to pierwsze dni czerwca 1946 roku, zacząłem organizować parafię i życie parafialne. Przeżyłem wiele wzruszających momentów. Ludzie na ogół niechętnie osiedlali się, gdzie nie było katolickiego księdza i kościoła. Byli więc przygnębieni, spłoszeni, żyjący psychozą tymczasowości. Toteż ukazanie się w stroju liturgicznym kapłana wywoływało olbrzymi, często spontaniczny entuzjazm. Wybiegali na spotkanie, witali ze łzami w oczach, rozmawiali, przyjmowali, w wielu miejscowościach wychodzili na spotkanie z krzyżem, wiankami i tak wprowadzano do wioski. Teren rozległy, w parafii 1572 dusze, założyłem dwa punkty sakralne w byłej remizie strażackiej we wsi Kamionka i Nakomiadach ${ }^{30}$.

We wrześniu 1946 r. ks. Szabunia ${ }^{31}$ był już w Kętrzynie, został rektorem kościoła św. Jerzego. Wspólnie z wiernymi odbudował plebanię, w której ulokowały się wnet siostry zakonne. Szybko uporządkował i wyremontował kościół, uczył młodzież religii w szkołach, został kapelanem w szpitalu. W 1954 r. przybył do Bartoszyc. Bez przerwy inwigilowany przez UB. W jednym z raportów Służby Bezpieczeństwa zanotowano:

sprawa operacyjna obserwacji $\mathrm{Nr} 1229$ prowadzona na dziekana dekanatu Bartoszyce ks. Adama Szabunię. Jest to były członek AK wileńskiego w $1945 \mathrm{r}$. jako repatriant przybywa na Ziemie Odzyskane do miejscowości Giżycko, a następnie przeniesiony do Kętrzyna, skąd przybył do Bartoszyc. Od samego początku wykazuje on wrogi stosunek do władzy ludowej... wymieniony nie chce podporządkować się władzy administracyjnej, bez zezwolenia w 1957 r. wyprowadził procesję na ulice miasta... Polecił swym podwładnym proboszczom i wikarym, aby masowo organizowali punkty katechetyczne, których zabronił im rejestrować i zgłaszać do Wydziału Oświaty ${ }^{32}$.

Ks. Szabunia tak opisał swą pracę duszpasterską po przybyciu do diecezji warmińskiej:

budowy, remonty, wkłady ofiar wiernych i ich praca działały konstruktywnie na psychikę ludności, przybyłej na te tereny z różnych stron. Psychoza tymczasowości i niepewności ustępowała na rzecz stabilności i nieodwracalności wyroków historii odnośnie do słusznych i sprawiedliwych praw Narodu Polskiego do odwiecznie polskich ziem odzyskanych Zachodnich i Północnych. Praca kapłanów była bardzo ciężka, zwłaszcza gdy się zważy wielki brak kapłanów, konglomerat ludności itp., ale wielkie umiłowanie Boga i Ojczyzny i Ludu Bożego było bodźcem do nieraz wprost heroicznych wysiłków i godnych podziwu sukcesów ${ }^{33}$.

Ibidem, s. 130-131 
Praca duszpasterska wymagała ofiarności kapłanów. Ksiądz Stanisław Adamski, który z Orzysza w 1955 r. przybył do parafii Kalnik niedaleko Morąga, tak ją opisał:

na terenie parafii Kalnik istnieją 4 kościoły czynne, przy czym takich odległości nie notuje żadna chyba placówka duszpasterska - odległość od Strużyny szosą wynosi 14,5 km, od drugiego kościoła filialnego w Chojniku - $12 \mathrm{~km}$, od trzeciego w Kwitajnach - 2,5 km. Każda niedziela lub święto kończy się przejechaniem w sumie 54 km drogą bitą i okrężną i z powrotem na śniadanie o godzinie około 19-tej ${ }^{34}$.

Owe odległości pokonywał ks. Adamski każdej niedzieli zaprzęgiem konnym czy rowerem, a czasami nawet pieszo i to bez względu na pogodę.

W Ełku - mieście do roku 1945 ewangelickim - katolicy posiadali kościół św. Wojciecha. Wspólnota katolicka w porównaniu z ewangelicką była niewielka. Ksiądz katolicki nie opuścił jednak Ełku, gdy do miasta zbliżały się wojska sowieckie. Proboszcz parafii św. Wojciecha, Warmiak, urodzony w Biskupcu, Karol Fox, który w Ełku był od 1919 r., nie opuścił mieszkańców ${ }^{35}$. W czasie II wojny światowej opiekował się polskimi jeńcami i robotnikami przymusowymi, znał język polski. Z małą grupką parafian w styczniu 1945 r. pozostał w mieście, uchronił kościół katolicki i przyjmował pierwszych polskich osadników. W pamięci mieszkańców pozostało nabożeństwo, które ks. Fox odprawił w maju $1945 \mathrm{r}$. W kościele zgromadziło się około 80 wiernych. Modlili się za tych, którzy zginęli, za tych, którzy opuścili Ełk, i za tych, którzy do niego przybyli. Administrator diecezji warmińskiej ks. Bensch pozostawił go w parafii św. Wojciecha. Tenże szanowany ksiądz musiał jednak Ełk opuścić, gdyż władzom nie podobała się jego działalność. W 1946 r. został przeniesiony do parafii w Starych Juchach. Tu objął opieką nie tylko katolików, lecz także Mazurów, niósł pomoc dzieciom i sierotom wojennym. Żył skromnie. Jego pogrzeb stał się w 1953 r. wielką manifestacją wiernych. Z Olsztyna do Starych Juch na uroczystości pogrzebowe przyjechał też ówczesny rządca diecezji, ks. Wojciech Zink. Ksiądz Fox w Ełku zgromadził wokół siebie katolików polskich i niemieckich. Po straszliwej wojnie podjął proces pojednania dwóch narodów, a jednocześnie rozpoczął proces integracji nowych przybyszy z nową ziemią. Również w Braniewie katolicy polscy i niemieccy modlili się w jednym kościele, a w kwietniu 1946 r. szli w uroczystej procesji przenoszącej z kościoła Świętej Trójcy do kościoła Świętego Krzyża cudowny obraz tej świątyni oraz kopię obrazu Matki Boskiej Nieustającej Pomocy. W parafialnych dokumentach zanotowano: Polacy szli zgodnie obok Niemców, a splendoru zewnętrznego dodawał jeszcze pluton wojska ${ }^{36}$. W 1946 r., gdy na ulice miast i wsi wyruszyły procesje Bożego Ciała, to wszyscy mieszkańcy, bez względu na narodowość, brali w nich udział. W Kętrzynie zwornikiem

Ibidem, s. 141.

S. Achremczyk, Ełk..., s. 330-331. 
łączącym ludzi był ks. Wacław Radziwon, chrzcił dzieci, dawał śluby, żegnał umar$ł_{y c h}{ }^{37}$. On połączył węzłem małżeńskim młodego Niemca Alfreda i Wandę, mieszkankę powiatu brasławskiego. Mieszkańcy pomagali remontować świątynie, czynili to $\mathrm{z}$ ogromną ofiarnością i bezinteresownością. Upiększali kościoły obrazami czasami wykonanymi przez ludowych artystów, cieszyli się, gdy zagrały organy. To był proces zadamawiania się w nowych miejscach.

W ciągu trzech pierwszych powojennych lat zostały powołane struktury kościelne w diecezji warmińskiej, odbudowywano świątynie, w szkołach uczono religii, działał Caritas, państwowe uroczystości rozpoczynały się od nabożeństw. Wielkim wydarzeniem w Olsztynie stał się przyjazd arcybiskupa wileńskiego Romualda Jałbrzykowskiego, a jeszcze większym była wizyta prymasa Augusta Hlonda. Prymas z Warszawy przez Mławę, Działdowo, Nidzicę, Olsztynek jechał do Olsztyna. Wszędzie witano go niezwykle serdecznie. W Olsztynie 19 lipca 1947 r. wierni długo oczekiwali na prymasa. Dopiero o 21.35 dotarł on do miasta.

Przywitanie odbyło się przy krzyżu przy ulicy Warszawskiej, gdzie kilka dni przedtem zdjęto tablicę z napisem niemieckim, zasłaniającą poprzedni polski napis. Księdza Prymasa i towarzyszących mu księży z biskupem Benschem na czele uczciła orkiestra wojskowa, która odegrała hymn państwowy, wojsko prezentowało bron ${ }^{38}$.

Prymasa mową powitali Warmiacy - poetka Maria Zientara Malewska i Paweł Sowa. Na drugi dzień tłum wiernych wypełnił kościół św. Jakuba, żegnano prymasa okrzykiem „niech żyje prymas”. Prymas zaś odpowiadał „niech żyje Olsztyn”. Nie wiedziano wówczas, że przed prymasem Hlondem jest zaledwie kilka miesięcy życia. Po jego śmierci papież Pius XII mianował następcą Hlonda 16 listopada 1948 r. biskupa lubelskiego Stefana Wyszyńskiego. Wyszyński został arcybiskupem metropolitą warszawskim i gnieźnieńskim i zarazem prymasem Polski. W Polsce tymczasem Kościół doznawał szykan ze strony władz państwowych. Już we wrześniu 1945 r. władze państwowe ogłosiły konkordat ze Stolicą Apostolską za nieobowiązujący. W 1948 r., a i wcześniej, władze zaczęły odsuwać księży od działalności społecznej w organizacjach społecznych. Nasilała się krytyka duchowieństwa przeszkadzającego w budowaniu ustroju sprawiedliwości społecznej. Im bardziej umacniała wpływy PPR, tym ostrzej krytykowano Kościół. Zaczęto zabierać mienie będące w posiadaniu Kościoła, księży usuwano ze szpitali i szkół, ograniczono działalność Caritas. We Fromborku zabrano diecezjalny dom pątnika, dom biskupi, kanonie, konfiskowano majątki kościelne, ziemie należące do parafii przekazywano PGR. W Ełku siostry benedyktynki misjonarki zostały pozbawione Domu Dziecka, w którym opiekowały się wojennymi sierotami. Ale nie poddawały się, nie zaprzestały opieki nad dziećmi, zajęły się dziećmi, którymi nikt nie chciał się opiekować, niepełnosprawnymi. Nastąpiły pierwsze aresztowania księży pod zarzutem wrogiej

Kętrzyn - moja nowa Ojczyzna..., s. 52. 
działalności. Zapadały wyroki śmierci zamieniane na dożywotnie więzienie, wielu skazano na kilkuletnie pobyty w więzieniach. Ksiądz Stanisław Adamski, który w latach 1948-1955 był proboszczem parafii Najświętszego Serca Pana Jezusa w Orzyszu, tak opisał swe kłopoty z władzą ludową:

W roku 1950 w gmachu Starostwa Powiatowego w Piszu wręczono mi listę zawierającą 1012 moich rzekomych wykroczeń natury państwowo-społecznej. Punkty brzmiały groźnie i oceniły mnie jako wroga Polski Ludowej i nielojalnego obywatela. Odtąd szykany w mniej lub więcej wyraźnej formie trwały cały czas. Wyraziły się one w usunięciu mnie ze szkoły, dwukrotnych porwaniach celem sterroryzowania i wymuszenia współpracy drogą gróźb, domiarów, kar i złośliwych pogróżek anonimowych żądających np. w ciągu dwóch tygodni opuszczenia Orzysza, inaczej miałem być zlikwidowany. Ta szarpanina nerwowa trwała lata i była prowadzona przez podwójne organa: miejscowej informacji wojskowej i bezpieczeństwa publicznego. Do ostatniej niemal chwili, bo do roku 1955 trwały najazdy służby bezpieczeństwa, aby mnie złamać i wymusić kompromis. Dnia 5 lipca 1955 roku z ust ks. ordynariusza Stefana Biskupskiego dowiedziałem się, że życzeniem władz państwowych jest, aby mnie usunąć poza granice diecezji ${ }^{39}$.

Ksiądz Adamski mimo gróźb i szykan nie został aresztowany. Z kolei ks. Nikodema Masłowskiego, osiadłego w Węgorzewie, gdy nie podpisał protestu skierowanego przeciw papieżowi Piusowi XII, władze oskarżyły o wystawianie fałszywych dokumentów, a nawet o współudział w zabójstwie trzech funkcjonariuszy ORMO. W listopadzie 1948 r. został aresztowany i osadzony w więzieniu w Olsztynie ${ }^{40}$. Do więzienia trafił ks. Giedymin Pilecki, ks. Stanisław Bogucki ${ }^{41}$, ks. Jan Stępień (na Warmii pracował pod nazwiskiem Stanisław Janczar) ${ }^{42}$. Nie uniknął aresztowania ks. Feliks Kowalik, który jesienią 1945 r. przybył do Górowa Iławeckiego. W 1949 r. przestraszony masowymi aresztowaniami żołnierzy Armii Krajowej wyjechał do Warszawy, ale i tam władze bezpieczeństwa go odszukały i w grudniu 1952 r. wtrąciły do mokotowskiego więzienia ${ }^{43}$. Nie sposób wymienić wszystkich aresztowanych księży. Kościoły parafialne wiejskie nie tak dawno obsadzone, odbudowane, uporządkowane, pełne wiernych, nagle pozbawione zostały duszpasterzy. Wreszcie w styczniu $1951 \mathrm{r}$. usunięto z Ziem Odzyskanych administratorów apostolskich powołanych w 1945 r., ogłoszono też dekret o obsadzaniu stanowisk kościelnych. Kościół w Polsce znalazł się w ogniu krytyki i otwartej walki z władzą komunistyczną. W sytuacji,

K. Bielawny, op. cit., s. 140.

40 A. Kopiczko, Ksiqdz Nikodem Masłowski 16 II 1889 - 24 VIII 1978, „Warmińskie Wiadomości Diecezjalne" 1995, nr 15, s. 49-51.

41 Idem, Bogucki Stanisław, [w:] Leksykon Duchowieństwa represjonowanego w PRL w latach 1945-1989, red. J. Myszor, t. 1, Warszawa 2002, s. 21-23.

42 H. Sieński, Stępień Jan Piotr, [w:] Leksykon Duchowieństwa represjonowanego..., t. 1, s. 268-270.

43 S. Kowalik, Kowalik Feliks, [w:] Leksykon Duchowieństwa represjonowanego..., t. 1, s. 129-131. 
gdy upaństwawiano zakłady przemysłowe, gdy zaczęto zakładać kołchozy, gdy własność prywatną potępiano, gdy likwidowano wszelkie organizacje katolickie, samorządowe, gdy jedyną słuszną partią stawała się PZPR, następował proces dezintegracji społeczeństwa na Ziemiach Zachodnich i Północnych. Prymas Wyszyński, dostrzegając ów proces, osobiście zaczął odwiedzać Ziemie Zachodnie i Północne. Na jego drodze nie zabrakło diecezji warmińskiej. W Olsztynie po raz pierwszy pojawił się 26 sierpnia 1950 r. ${ }^{44}$ Obchodzono wówczas pięciolecie kościelnej polskiej administracji na Warmii i pięciolecie rządów w diecezji ks. dra Teodora Benscha. Prymas przebywał wówczas w diecezji dziesięć dni. Był nie tylko w Olsztynie, lecz także w Malborku, Elblągu, Fromborku, Dobrym Mieście, Lidzbarku Warmińskim, Gietrzwałdzie, Świętej Lipce, Giżycku, Kętrzynie i Grunwaldzie. Urząd Bezpieczeństwa i władze partyjne w Olsztynie bacznie obserwowały tę wizytę. Prymas odwiedził wszystkie pięć kościołów olsztyńskich, wygłosił kazanie w kościele św. Józefa i św. Jakuba, w dniach 28-29 sierpnia miał konferencję z duchowieństwem diecezjalnym już dzielonym przez władze na księży patriotów i politycznych przeciwników. Agenci, których wcale nie było mało, informowali o antykomunistycznych homiliach prymasa. W listopadzie 1950 r., po wizycie w diecezji, prymas napisał specjalny list do ks. Benscha, w którym jakby podsumował pięcioletnie rządy administratora apostolskiego:

Nie mogę oprzeć się jednej myśli: skoro Opatrzność Boża przywiodła znów Państwo Polskie na te ziemie, to nie dla grymasów dziejów; jest to brzemienna w następstwa chwila, w której boskie poczucie odpowiedzialności za chwilę obecną, stanęły mi ziemie krzyża miłości i miecza wyniszczenia, dźwiganego z gruzów Malborka i zburzonej kwatery głównej Hitlera, zapomnianych pól Grunwaldu i wymownych złomów pychy Tannenbergu. Są to ziemie niezwykłych syntez historycznych od Malborka po Kętrzyn i od wspaniałej katedry fromborskiej po olsztyńską katedrę św. Jakuba. Są to ziemie dziejowej próby wartości dzieł miłości i nienawiści. Bo ostał się w wierności Ojczyźnie lud warmiński. Na czułych wagach dziejowych odmierzano nam dziś sprawiedliwość; jest to chwila restytucji za wylane łzy i krew, za cierpienie i upokorzenia... Wróciłem z Warmii i Ziemi Mazurskiej głęboko wzruszony ogromem błogosławieństwa pracy Kościoła dla Ziem Odzyskanych. Widziałem lud wypełniający świątynie, widziałem kapłanów niezmordowanych w trudzie, widziałem Seminarium Duchowne w pełni rozwoju, widziałem diecezję warmińską doskonale zorganizowaną, poziomem swej pracy nie ustępującej w niczym diecezjom centralnym w kraju ${ }^{45}$.

44 M.P. Romaniuk, Życie, twórczość i posługa Stefana Kardynała Wyszyńskiego Prymasa Tysiaclecia, Warszawa 1994, s. 430; J. Chłosta, Zwiqzki Prymasa Polski - Stefana Kardynała Wyszyńskiego z Warmia, [w:] Stefan Kardynał Wyszyński wobec Ziem Zachodnich i Północnych oraz stosunków polsko-niemieckich, red. T. Dzwonkowski, Cz. Osękowski, Warszawa-Poznań-Zielona Góra 2001, s. 156-157; S. Achremczyk Prymas Stefan Wyszyński na Warmii i Mazurach, [w:] Między historiq politycznq a społecznq. Księga jubileuszowa ofiarowana Profesorowi Andrzejowi Skrzypkowi w siedemdziesięciolecie urodzin, red. J. Gołota, Pułtusk-Olsztyn-Ostrołęka-Warszawa 2014, s. 241.

45 Prymas Polski Stefan Wyszyński, List Prymasa Polski z 8 XI 1950, „Warmińskie Wiadomości Diecezjalne" 1950, nr 5, s. 2-4; M.F. Romaniuk, op. cit., s. 430; S. Achremczyk, Prymas Stefan Wyszyński na Warmii i Mazurach..., s. 242. 
Tymczasem ks. dr Bensch, który tak dobrze zorganizował diecezję, został 26 stycznia 1951 r. decyzją rządu usunięty od sprawowania stanowiska administratora apostolskiego. Prymas szybko, bo 30 stycznia 1951 r., sankcjonował wybór na wikariusza generalnego ks. Wojciecha Zinka dokonany przez Radę Konsultorów ${ }^{46}$. Warmia jednak nie miała swego biskupa, dlatego też święceń kapłańskich udzielał czasami prymas Wyszyński. I tak 16 czerwca 1952 r. udzielił święceń sześciu diakonom i trzydziestu niższych święceń w kościele św. Jakuba w Olsztynie. W tym samym czasie w Pieniężnie konsekrował werbistów. Prymas odwiedził również parafię w Sząbruku. Następnego dnia, 17 czerwca, rano odprawił nabożeństwo w katedrze olsztyńskiej, w gmachu kurii spotkał się z dziekanami, dla których wygłosił referat „Duszpasterz wobec przemian ustrojowych w Polsce”. Tego samego dnia prymas z Olsztyna udał się do Pięniężna, do księży werbistów ${ }^{47}$. Rok później ponownie przyjechał do Olsztyna i znów udzielał święceń kapłańskich. Wierni witali go serdecznie, ustawiali bramy powitalne, wywieszali transparenty. Ludzie nie bali się, choć nazwiska tych, którzy witali prymasa, odnotowywali agenci Urzędu Bezpieczeństwa. W sierpniu 1953 r. prymas Wyszyński zjechał na Warmię na krótkie wakacje. Przez dziesięć dni od 5 sierpnia wypoczywał w Orzechowie, wsi zagubionej wśród lasów i jezior południowej Warmii. To piękne miejsce wynalazł dla niego ks. Zink. Dla miejscowej ludności był księdzem Profesorem. Poznał wówczas jeszcze bardziej problemy Warmii i ludność tak gorliwie religijną. Po latach o pobycie w Orzechowie pisał:

spotykani ludzie niemal wszyscy mówią po polsku, nie spotkaliśmy takiego, który nie rozumiał języka polskiego. Wszyscy dobrze odpowiadają pochwalonego czystym językiem. Najlepiej mówią chłopcy po wojsku; znać na nich, że otarli się o wymowę literacką. Bez błędów zazwyczaj mówią starsi, chociaż w fonetyce ulegają niemieckiej manii charczenia. Najgorzej mówią dziewczęta, które mają najmniej kontaktów z Polską, nasza miejscowość to krawędź Warmii. Lud jest bardzo religijny, każdego dnia naszego pobytu przychodziło kilka osób do spowiedzi i przeszło 10 osób do komunii św. Dobrze śpiewają po polsku, wiele pieśni nowych, chociaż można tu znaleźć i śpiewniki niemieckie. Modlitewnik diecezjalny, po polsku, jest dobrze zredagowany, ale są to książki przedwojenne. Dziś cenzura nie pozwala drukować książek religijnych dla tych ludzi. Jest to zbrodniczość, nie dająca się obliczyć w następstwach swoich. Z braku książek polskich ludzie ci z konieczności sięgają po książki niemieckie. A tu trzeba by dać to, co budzi zaufanie. Ludzie ci nie wezmą do ręki komunistycznej gazety i książki. Łudzi się Rząd, gdy myśli, że można repolonizować tych ludzi na lekturze o Marksie, Engelsie, Stalinie i bohaterach Polski Ludowej. Oni ich nie rozumieją i nie chcą znać. Natomiast chętnie czytaliby historię Narodu polskiego i literaturę polską. Nieszczęściem Polski jest, że Warmia wróciła w okresie komunizowania Polski. Ale przeszli zwycięsko przez germanizację, to przejdą i przez komunizm ${ }^{48}$.

46 S. Brewczyński, Ks. Adalbert (Wojciech) Zink. Rzadca diecezji warmińskiej w latach 1951-1953, Olsztyn 2006, s. 56-59; Śp. Ks. Infułat Wojciech Zink, „Warmińskie Wiadomości Diecezjalne” 1970, nr 2, s. 5356; J. Obłąk, A. Kopiczko, op. cit., s. 141-143.

47 M.F. Romaniuk, op. cit., s. 528; S. Achremczyk, Prymas Wyszyński na Warmii i Mazurach..., s. 243; J. Chłosta, Zwiqzki prymasa..., s. 157. 
Na tablicy upamiętniającej poległych w I wojnie światowej w kształcie świecznika naliczył prymas 42 nazwiska, w tym 30 posiadających brzmienie polskie. Prymas Wyszyński dość szybko zapoznał się z położeniem Warmiaków. W 1950 r. w ówczesnym województwie olsztyńskim ludności warmińskiej miało być 37 tys. ${ }^{49} \mathrm{~W} 1960 \mathrm{r}$. tylko w powiecie olsztyńskim Warmiaków mieszkało 25600 osób ${ }^{50}$. Ludność ta zachowała własną obrzędowość, na co dzień posługiwała się gwarą warmińską, ale mówiła też po polsku i po niemiecku. Ludność autochtoniczna nieznająca języka polskiego domagała się odprawiania nabożeństw w języku niemieckim. W tej sprawie do władz lokalnych zwracali się proboszczowie z południowej Warmii - ks. Maksymilian Tarnowski z Barczewa, ks. Edward Barkowski z Bartąga, ks. Franciszek Siłakowski z Brąswałdu, o. Stanisław Sobieszczyk z Giław. W parafii Bartąg w 1951 r. zebrano 1218 podpisów pod prośbą o nabożeństwa $\mathrm{w}$ języku niemieckim. Władze nie godziły się na takie prośby, oskarżając księży o propagowanie nacjonalistycznej niemieckiej propagandy. Wbrew władzom w niektórych kościołach głoszono kazania po niemiecku, śpiew był niemiecki. Pogrzeb ks. Alfonsa Wardeckiego, proboszcza parafii NSPJ w Olsztynie, stał się okazją dla Warmiaków do zaakcentowania potrzeby liturgii w języku niemieckim ${ }^{51}$. Poczynania władz nie sprzyjały procesowi integracji nawet polskich Warmiaków z polskimi sąsiadami. Warmiacy nie znali zwyczaju dzielenia się opłatkiem w czasie wigilii Bożego Narodzenia. W wigilię zaś mieszkańców odwiedzali kolędnicy. Kolędy śpiewali Warmiacy po uroczystej Pasterce. Przez długi czas nie święcono na Warmii pokarmów w Wielką Sobotę. W parafiach warmińskich w niedzielę o godzinie 15.00 odprawiano popołudniowe nieszpory ${ }^{52}$. Była to ludność niezwykle pracowita i pobożna ${ }^{53}$.

Następnym razem prymas Wyszyński był na Warmii jako więzień przetrzymywany w Stoczku Klasztornym ${ }^{54}$. W nocy 25 września 1953 r. prymas został aresztowany. W partyjnym „Głosie Olsztyńskim” ukazał się lakoniczny komunikat Prezydium Rządu:

Prezydium Rządu w oparciu o swe uprawnienia ustawowe i w trosce o pełną realizację stosunków między Rządem a hierarchią kościelną - zakazało arcybiskupowi Stefanowi Wyszyńskiemu wykonywania funkcji związanych z dotychczasowymi stanowiskami kościelnymi ${ }^{55}$.

50 J. Obłąk, A. Kopiczko, op. cit., s. 208; A. Kopiczko, Kościół warmiński a polityka wyznaniowa po II wojnie światowej..., s. 81; W. Piwowarski, Typologia religijna katolików południowej Warmii, „Studia Warmińskie", t. I (1964), s. 129-132.

51 S. Brewczyński, op. cit., s. 123-124.

52 A. Szyfer, Ludowe zwyczaje, obrzędy, wierzenia i wiedza, [w:] Kultura ludowa Mazurów i Warmiaków, red. J. Burszta, Wrocław 1976, s. 409-415; Eadem, Tradycyjne wierzenia i zwyczaje okresu Bożego Narodzenia na Warmii, „Komunikaty Mazursko-Warmińskie” 1965, nr 4, s. 569-580; Eadem, Warmiacy: studium tożsamości, Poznań 1996, passim; J. Chłosta, Doroczne zwyczaje i obrzędy na Warmii, Olsztyn 2009, s. 16-17, 31-48; E. Ferenc, Rok kościelny a polskie tradycje, Poznań 1997.

53 W. Piwowarski, op. cit., s. 141-142, 158-164.

54 Kardynał S. Wyszyński, Zapiski więzienne, Paryż 1982, s. 35-36, 50, 52-92. 
Na Warmii odczytania w kościołach tego komunikatu odmówił wikariusz kapitulny ks. Wojciech Zink. 3 października 1953 r. został aresztowany i osadzony w więzieniu mokotowskim w Warszawie ${ }^{56}$. Na wolność wyszedł on 24 stycznia 1955 r. We wspomnieniach prymas Wyszyński odnotował, że ujął się za nim pies i ksiądz Niemiec. Dla diecezji warmińskiej nastały najtrudniejsze w powojennej historii lata ${ }^{57}$. Uderzenie w Kościół miał przynieść tzw. ruch księży patriotów. Władza starała się podzielić duchowieństwo na tych, którzy popierali nową rzeczywistość, i na tych, których zaliczała do wrogów ludowego państwa. Zorganizowano stowarzyszenie zwane Komisją Księży przy Związku Bojowników o Wolność i Demokrację. Księży należących do tej komisji promowano do obsadzania znaczących parafii. Następnie utworzono Zrzeszenie Katolików Caritas, tworzono też inne komisje. W 1955 r. według władz około 150 księży w diecezji warmińskiej uznawały zmiany ustrojowe zaszłe w Polsce. Księża patrioci zastępowali księży Warmiaków w warmińskich parafiach. Pojawili się oni w Sętalu, Purdzie, Barczewie. W czasach stalinowskich zamykano stowarzyszenia katolickie, których wiele powstało po 1945 r., diecezjalny Caritas także zaprzestał działalności, a przecież do grudnia $1946 \mathrm{r}$. zorganizowano aż 84 parafialne oddziały Caritasu. W Olsztynie kuchnia prowadzona przez Caritas wydawała około 5 tys. obiadów miesięcznie. W pierwszych latach ogromnej biedy zdołano utworzyć bursy, przytułki dla osób starszych, sierocińce, przedszkola, żłobki, świetlice, biblioteki. Caritas organizował kolonie letnie dla dzieci, pomagał chorym. Ze szkół usunięto nauczanie religii, pozamykano kaplice w szpitalach, uniemożliwiono drukowanie książek katolickich, modlitewników czy śpiewników. Odbudowa albo zwykły remont kościołów stawał się niemożliwy. Wiele zabytkowych kościołów zostało zdewastowanych. Wreszcie pozbawiono Kościół mienia oraz majątków ziemskich.

Zmiany przyniósł rok 1956. W październiku tr. olsztyński oddział „Słowa Powszechnego" odważył się nawet napisać petycję do Władysława Gomułki, domagającą się uwolnienia prymasa Wyszyńskiego z więzienia. W 1956 r. diecezja otrzymała biskupa w osobie Tomasza Wilczyńskiego. Wilczyńskiemu przyznano tylko tytuł biskupa w Olsztynie, ale jego nominacja była krokiem normalizowania sytuacji Kościoła na Ziemiach Odzyskanych. W swym pierwszym liście pasterskim biskup Wilczyński stawiał na „stałość i pewność”, pisząc do diecezjan:

Ludy bez ziemi, wędrowne, nie tworzyły wielkich kultur ani cywilizacji, ale ludy osiadłe. Można jednak nie wieść życia wędrownego w sensie fizycznym, lecz można być duchowym wędrowcem, który ciągłą myślą i tęsknotami wybiegającymi poza teren rzeczywistego zamieszkania, utrudnia ład wewnętrzny swego żywota ${ }^{58}$. 
Biskup apelował, by nowi osadnicy czuli się na nowej ziemi domownikami, gospodarzami, bo tylko wówczas zapewnią dobrą przyszłość sobie i swym potomkom. Nie zapomniał Wilczyński o Warmiakach, miejscowych, jak pisał, którzy pozostali na ziemi przodków, choć traktowano ich po macoszemu. W tym samym liście pasterskim nadmieniał:

Są wierni w tej diecezji wrośnięci od wieków w ojczystą glebę. Nie zawsze traktowano ich po bratersku. Pamiętamy o ich długim trwaniu na tej ziemi, o ich przywiązaniu do Kościoła i narodowego obyczaju. Przetrwali, a prochy ich dziadów, które obficie zgromadziła ta ziemia, świadczą chlubnie o ich łączności z historią naszego narodu. Lud ten polski, warmiński lud, wierny Bożej rodzicielce w Świętej Lipce i Gietrzwałdzie ${ }^{59}$.

Po okresie weryfikacji narodowej, wysiedleniach za granicę i pozbawianiu praw publicznych, a zwłaszcza możliwości posługiwania się swoim językiem, miejscowa ludność została zauważona. Biskup Wilczyński wykonał piękny gest wobec niej, mianując wikariuszem generalnym ks. Wojciecha Zinka. A jednak Warmiacy zaczęli wyjeżdżać do Niemiec. Prymas Wyszyński, przemierzając Warmię, dostrzegał owe zmiany i ubolewał, że Warmiacy opuszczają swą ojczyznę. W 1966 r. w notatkach Pro memoria pisał:

Przejazd przez Świętą Warmię okazuje oblicze zaszłych zmian. Dawniejszej ludności warmińskiej - niemal nie ma; wyjechała do Niemiec, chociaż wielu walczyło o przyjście do Polski. Polska Ludowa obeszła się z nimi jak z Niemcami. Nie wytrzymali systemu, chociaż duchowieństwo bardzo prosiło o złagodzenie tego systemu i nalegało na cierpliwość. Głosiłem kiedyś kazanie w Gietrzwałdzie do gromady Warmiaków. Siedzieli godni, niewzruszeni, swoje myśleli. W kilka lat wszyscy niemal opuścili teren, pozostawili Matkę Bożą Gietrzwałdzką, która kiedyś - za czasów niewoli - przemawiała tu po polsku ${ }^{60}$.

Gdy biskup Wilczyński obejmował rządy w Olsztynie, diecezja warmińska liczyła 800 tys. wiernych, dwa razy więcej niż w 1946 r. W 1957 r. jeden ksiądz, a było ich wówczas 334, musiał obsługiwać 2 tys. wiernych. Kapłanów było wciąż mało, nic dziwnego, że biskup Wilczyński zachęcał duchownych z innych diecezji, by przyjeżdżali na Warmię. Przybywało jednak młodych, którzy święcenia kapłańskie otrzymali na Warmii. W 1957 r. do Seminarium Duchownego zgłosiło się 80 kandydatów. Z 280 młodzieńców, którzy zgłosili się za rządów biskupa Wilczyńskiego do Seminarium Duchownego, święcenia otrzymało 182, z czego z rąk samego biskupa 154. Z tych 182 tylko czterech urodziło się w diecezji warmińskiej, 39 przybyło z diecezji tarnowskiej, 26 płockiej, 24 łomżyńskiej, 22 lubelskiej, 20 chełmińskiej, 18 z Kresów Wschodnich ${ }^{61}$. 
Biskup Wilczyński niestrudzenie wizytował parafie, pomagał w zdobywaniu wyposażenia liturgicznego. W 1960 r. w sprawozdaniu o stanie diecezji, przesłanym do Stolicy Apostolskiej, zaznaczył, iż nie odwiedził tylko dwóch placówek i to tylko dlatego, że w jednej zmarł proboszcz, a w drugiej władze państwowe nie zgodziły się na mianowanie proboszcza. Tworzył nowe placówki duszpasterskie. W $1962 \mathrm{r}$. do rangi parafii podniósł aż 79 kościołów. W czasie jego rządów zbudowano nowy kościół w Starych Jabłonkach. On wprowadzał posoborowe zmiany w warmińskim Kościele. Czasy nie były łatwe, po krótkiej odwilży, gdy księża wrócili do szkół, dla szpitali nastał czas zupełnie odwrotny. Lekcji religii w szkołach nie było, księży nakazano wycofywać ze szpitali, Seminarium Duchownemu zabrano budynek przy ulicy Mariańskiej ${ }^{62}$, zatrzymano peregrynację obrazu Matki Boskiej Częstochowskiej po diecezji.

Swe rządy mógł podsumować biskup Wilczyński podczas uroczystych obchodów 20-lecia polskiej administracji kościelnej na Ziemiach Zachodnich i Północnych. Wielkie uroczystości 19 czerwca $1965 \mathrm{r}$. zorganizowano w Olsztynie. W niedzielę, 13 czerwca 1965 r., w kościołach diecezji odczytano komunikat biskupa Tomasza Wilczyńskiego informujący, że 20 czerwca w kościele NSPJ w Olsztynie o godzinie 10.00 odbędzie się uroczysta msza św. z udziałem prymasa Wyszyńskiego i biskupów Ziem Zachodnich oraz diecezji sąsiadujących z Warmią. Na placu przy kościele NSPJ zbudowano ołtarz polowy, zaprojektowany przez ks. kanonika warmińskiego Henryka Gulbinowicza, a wykonany przez pracowników Teatru im. Stefana Jaracza przy udziale ks. Juliana Żołnierkiewicza ${ }^{63}$. Na uroczystość oprócz prymasa przyjechał z Wrocławia arcybiskup Bolesław Kominek, biskup Franciszek Jop z Opola, arcybiskup krakowski Karol Wojtyła i jeszcze piętnastu innych. To była wielka manifestacja religijna. Mszę św. odprawił arcybiskup Kominek, a kazanie wygłosił prymas Wyszyński. Witając dostojnych gości i wiernych, biskup Wilczyński powiedział:

Kościół w swym wewnętrznym życiu dzieli dolę ziemską swych wiernych. Na Warmii organizacja kościelna została zniszczona, świątynie w większości bądź zburzone, bądź poszczerbione, szaty i sprzęt liturgiczny zniszczony. Ludność miejscowa w swej większości uprowadzona za Odrę. Piękna Kraina Tysiąca Jezior spłynęła krwią i ziała pustką zniszczenia ${ }^{64}$.

A jednak podniosła się ze zniszczeń, choć ślady wojny wciąż były widoczne. Do słów biskupa Wilczyńskiego nawiązał w swej homilii prymas Wyszyński. Prymas zwrócił uwagę na ogromną rolę Kościoła w zagospodarowywaniu nowej rzeczywistości, na oddalaniu poczucia tymczasowości. Wyszyński mówił:

62 Idem, Zarys powojennych dziejów seminarium Hosianum, „Studia Warmińskie”, t. XXXIV (1997), s. 206-207.

63 A. Kopiczko, J. Żołnierkiewicz, op. cit., s. 150-151.

64 Ibidem, s. 152. 
Gdzie stanął kapłan katolicki z krzyżem i ewangelią, tam też gromadziła się około niego napływająca ludność pozbawiona własnych domostw. Bo tu był duch Ewangelii, słyszanej z ambon tylu świątyń. Zalękniony lud, bez ojczyzny i bez dachu nad głową, poczuł, że ktoś przemawia znajomym głosem, pokazuje ten sam znak krzyża jako nadzieję jedyną. Nic dziwnego, że lud zaczął nabierać wiary w naszą tu obecność i poczuł się na ojczystym. W pierwszych momentach niepewności i zwątpień Kościół dzięki swej wypracowanej przez wieki organizacji, umysłowi społecznemu i ładowi moralnemu dał od razu konstruktywne elementy, które były najsilniejszymi faktorami ładu i porządku oraz ostoją wiary w naszą przyszłość... Zasługi duchowieństwa polskiego i polskich biskupów są może nie zawsze doceniane, ale przyjdą czasy, gdy historia to oceni i wypowie należną nam sprawiedliwośćc5.

Takie nabożeństwa jednoczyły mieszkańców, znikały dzielnicowe uprzedzenia. Ledwo minął miesiąc, gdy Olsztyn przeżył smutną uroczystość. Zmarł 5 sierpnia 1965 r. biskup Tomasz Wilczyński. Pogrzeb biskupa odbył się 8 sierpnia w olsztyńskiej katedrze w obecności prymasa Wyszyńskiego. Następcą Wilczyńskiego został dotychczasowy sufragan, biskup Józef Drzazga.

Biskup Drzazga, który 13 lat kierował diecezją warmińską, podobnie jak biskup Wilczyński pochodził z diecezji lubelskiej. Jego rządy przypadły na okres posoborowy. Kościół otwierał się na świeckich. Diecezja warmińska w 1970 r., w roku 25-lecia polskiej organizacji kościelnej na Ziemiach Zachodnich i Północnych, liczyła 1150 katolików, posiadała trzech biskupów, 422 kapłanów diecezjalnych, 173 zakonnych, 420 sióstr zakonnych i 56 świeckich katechetek i katechetów ${ }^{66}$. W Polsce jednak Kościół spychany był na margines życia społecznego. W 1966 r. uroczyście obchodzono milenium chrztu. Milenium obchodzono w konfrontacji z władzami państwowymi. Na Warmii główne uroczystości odbyły się w czerwcu w Olsztynie i Fromborku. Przejechał na nie prymas i 42 biskupów. Katedra fromborska została podniesiona do godności bazyliki mniejszej. W roku 1967 odbyła się koronacja obrazu Matki Boskiej w Gietrzwałdzie. Gietrzwałd w zasadzie został odkryty dla wiernych. Co roku przybywały tu liczne pielgrzymki. W $1967 \mathrm{r}$. w homilii podczas 90-lecia objawień gietrzwałdzkich prymas Wyszyński chwalił Warmię za wierność Kościołowi mówił, że „Kościół jest żywy, ożywiający, uświęcający, krzepiący, macierzyński, godzący”67. Pielgrzymi zdążający do Gietrzwałdu szukają tu pokrzepienia, pokoju, „siły, która bez gwałtu i przemocy wszystko uspokaja, jednoczy, raduje". W homilii prymas wymienił dwóch warmińskich księży „najdostojniejszych i czcigodnych nestorów duchowieństwa warmińskiego" - księdza Wojciecha Zinka i księdza Jana Hanowskiego. O pierwszym mówił: „jako wikariusz kapitulny wiele wycierpiał od władz administra-

66 A. Kopiczko, Diecezja warmińska za rzq̨ów bp. Józefa Drzazgi (1965-1978). Zarys problematyki, [w:] Droga do stabilizacji polskiej administracji kościelnej na Ziemiach Zachodnich i Północnych po II wojnie światowej. W 40. rocznice wydania konstytucji apostolskiej Pawła VI Episcoporum Poloniae coetus, red. W. Kucharski, Wrocław 2013, s. 195-209. 
cyjnych, był człowiekiem, który całe życie dążył do Polski. A w ten sposób, jak z nim się obchodzono, mogłoby to największego przyjaciela uczynić wrogiem, choć nie złamało tego dzielnego Warmiaka"68. Księdzu Hanowskiemu dziękował prymas w specjalnym liście wcześniej, gdyż w roku 1960:

Za te bogactwa cnoty kapłańskiej i za Twoje bezgraniczne poświęcenie dla kościoła wynagrodzi Ci Bóg, ale zanim złożysz swe ciało do ziemi Zmartwychwstania, ta ziemia warmińska pragnie ci dzisiaj podziękować i oddać cześć. Pragnie ci podziękować za to, żeś był jej zawsze wierny, żeś jej nigdy nie zdradził. Ukochałeś lud warmiński i broniłeś jego wartości duchowych. Jako Dobry Pasterz, mimo zakazów, nie opuściłeś tego ludu, ale w jego mowie jednałeś z Bogiem w konfesjonale, nigdy nie zaprzestałeś odprawiania dla tego ludu nabożeństw dodatkowych w języku polskim. Co więcej, Ty byłeś nauczycielem tej mowy dla Braci Kapłanów i uczyłeś jej nawet tak zasłużonego dla Kościoła Księdza Prałata Wojciecha Zinka ${ }^{69}$.

Ważnym wydarzeniem, na które w Olsztynie czekano 27 lat, było powołanie 28 czerwca 1972 r. biskupa Drzazgi na biskupa rezydencjonalnego diecezji warmińskiej. W liście pasterskim informował diecezjan o tej ważnej decyzji Stolicy Apostolskiej, pisał:

Po raz pierwszy odzywam się do Was jako biskup warmiński... Na mocy decyzji Ojca Świętego Pawła VI diecezja nasza otrzymała w mojej osobie swego ordynariusza. Na tej podstawie staję w szeregu biskupów warmińskich jako pierwszy Polak od czasów Ignacego Krasickiego po dwuwiekowej przerwie ${ }^{70}$.

Poprzez wielkie uroczystości kościelne - rok kopernikański, stulecie Objawień Matki Bożej w Gietrzwałdzie biskup Drzazga wpływał na integrację mieszkańców Warmii i Mazur. W uroczystościach jubileuszowych stulecia Objawień do Gietrzwałdu przybyło 34 biskupów i ponad 100 tys. pielgrzymów. To wówczas w publicystyce pojawiło się określenie „odkrycie Gietrzwałdu”. Biskup Drzazga zmarł 12 września 1978 r. Pochowano go w kościele św. Jakuba. Jego następcą został Józef Glemp, a gdy awansowano go na prymasa Polski, na biskupa warmińskiego powołano Jana Obłąka. Biskup Obłąk ustąpił miejsca biskupowi Edmundowi Piszczowi. W okresie pontyfikatu biskupa Piszcza diecezję podniesiono do rangi metropolii.

68 J. Chłosta, Zwiq̨zi Prymasa..., s. 162.

69 Ibidem; S. Achremczyk, Prymas Stefan Wyszyński na Warmii i Mazurach..., s. 257-258. 


\section{Bibliografia}

Achremczyk S., Ełk. Dzieje miasta, Olsztyn 2012

Achremczyk S., Historia Warmii i Mazur, t. 2: 1772-2010, Olsztyn 2011

Achremczyk S., Orneta. Dzieje miasta, Olsztyn 2006

Achremczyk S., Prymas Stefan Wyszyński na Warmii i Mazurach, [w:] Między historiq politycznq a społecznq. Księga jubileuszowa ofiarowana Profesorowi Andrzejowi Skrzypkowi w siedemdziesięciolecie urodzin, red. J. Gołota, Pułtusk-Olsztyn-Ostrołęka-Warszawa 2014

Achremczyk A., Szorc A., Braniewo, Olsztyn 1995

Alejun Z.J., Syn Ziemi Wileńskiej ks. Adam Szabunia (1912-1981), Kętrzyn-Olsztyn 2010

Bielawny K., Dzieje parafii św. Brunona w Bartoszycach w XIX i XX wieku, Olsztyn 2009

Brewczyński S., Ks. Adalbert (Wojciech) Zink. Rzqdca diecezji warmińskiej w latach 1951-1953, Olsztyn 2006

Brzozowski K., Budzyński S., Korcz J., Sanktuarium Maryjne w Gietrzwałdzie. 125 rocznica objawień Najświętszej Maryi Panny, Warszawa 2002

Chłosta J., Doroczne zwyczaje i obrzędy na Warmii, Olsztyn 2009

Chłosta J., Jeszcze o biskupie Maksymilianie Kallerze, „Warmińskie Wiadomości Archidiecezjalne", nr 10 (1993), s., s. 126-133

Chłosta J., Maksymilian Kaller biskup warmiński w latach 1930-1947, [w:] Poczet biskupów warmińskich, red. S. Achremczyk, Olsztyn 2008

Chłosta J., Niezwykła posługa warmińskiego kapłana, „Studia Warmińskie”, t. 32 (1995), s. 365-377

Chłosta J., Zwiqzki Prymasa Polski - Stefana Kardynała Wyszyńskiego z Warmiq, [w:] Stefan Kardynał Wyszyński wobec Ziem Zachodnich i Północnych oraz stosunków polsko-niemieckich, red. T. Dzwonkowski, Cz. Osękowski, Warszawa-Poznań-Zielona Góra 2001

Ferenc E., Rok kościelny a polskie tradycje, Poznań 1997

Kętrzyn - moja nowa Ojczyzna. Wspomnienia mieszkańców, Olsztyn-Kętrzyn 2006

Kopiczko A., Bogucki Stanisław, [w:] Leksykon Duchowieństwa represjonowanego w PRL w latach 1945-1989, red. J. Myszor, t. 1, Warszawa 2002, s. 21-23

Kopiczko A., Diecezja warmińska za rzqdów bp. Józefa Drzazgi (1965-1978). Zarys problematyki, [w:] Droga do stabilizacji polskiej administracji kościelnej na Ziemiach Zachodnich i Północnych po II wojnie światowej. W 40. rocznicę wydania konstytucji apostolskiej Pawła VI Episcoporum Poloniae coetus, red. W. Kucharski, Wrocław 2013, s. 195-209

Kopiczko A., Ksiq̨z Nikodem Masłowski 16 II 1889 - 24 VIII 1978, „Warmińskie Wiadomości Diecezjalne", nr 15 (1995), s. 49-51

Kopiczko A., Ks. prof. Stefan Biskupski - objęcie urzędu wikariusza kapitulnego diecezji warmińskiej i charakterystyka jego pracy na tym stanowisku, „Studia Warmińskie”, t. 32 (1995), s. 379-388

Kopiczko A., Kościół warmiński a polityka wyznaniowa po II wojnie światowej, Olsztyn 1996

Kopiczko A., Tomasz Wilczyński biskup warmiński w latach 1956-1965, [w:] Poczet biskupów warmińskich, red. S. Achremczyk, Olsztyn 2008, s. 451-452

Kopiczko A., Zarys powojennych dziejów seminarium Hosianum, „Studia Warmińskie”, t. XXXIV (1997), s. 201-214.

Kopiczko A., Żołnierkiewicz J., Dzieje kościoła i parafii Najświętszego Serca Pana Jezusa w Olsztynie 1903-2003, Olsztyn 2004 
Kossert A., Ostpreussen. Geschichte und Mythos, München 2005

Kowalik S., Kowalik Feliks, [w:] Leksykon Duchowieństwa represjonowanego w PRL w latach 19451989, red. J. Myszor, t. 1, Warszawa 2002, s. 129-131

Kudrzycki Z., Dzieje Rozóg, Toruń 2003

Kudrzycki Z., Przemiany społeczno-polityczne na pograniczu mazursko-kurpiowskim po 1945, [w:] Migracja ludności na pograniczu mazursko-kurpiowskim w XIX i XX wieku, red. J. Gołota, OstrołękaOlsztyn 2008

Łukaszewicz B., Raptularz miejski, Olsztyn 1945-2005, Olsztyn 2006

Murawska H., Przesiedleńcy z Kresów Północno-Wschodnich II Rzeczypospolitej w Olsztyńskiem, Olsztyn 2000

Nowotka M., Przemiany ludnościowe na pograniczu mazursko-kurpiowskim po II wojnie światowej na przykładzie gminy Rozogi, [w:] Migracja ludności na pograniczu mazursko-kurpiowskim w XIX i XX wieku, red. J. Gołota, Ostrołęka-Olsztyn 2008

Obłąk J., Z powojennych dziejów diecezji warmińskiej. Luty-wrzesień 1945, „Polonia Sacra”, t. 8 (1956), z. 3-4, s. 401-403

Obłąk J., Kopiczko A., Historia diecezji i archidiecezji warmińskiej, Olsztyn 2010

Ornatek A., Biskup Maksymilian Kaller - wierność pasterskiemu powołaniu, „Warmińskie Wiadomości Archidiecezjalne", nr 8 (1993), s. 87-96

Ornatek A., W poszukiwaniu prawdy o biskupie Maksymilianie Kallerze, „Warmińskie Wiadomości Archidiecezjalne", nr 10 (1994), s. 133-138

Pietrzak J., Działalność kardynała Hlonda jako wysłannika papieskiego na Ziemiach Odzyskanych w 1945 r., „Nasza Przeszłość", t. 42 (1974)

Płotek M., Losy sierot narodowości niemieckiej z terenu Warmii i Mazur po zakończeniu II wojny światowej, „Komunikaty Mazursko-Warmińskie", nr 3 (2005), s. 349-362

Piwowarski W., Typologia religijna katolików południowej Warmii, „Studia Warmińskie”, t. I (1964), s. $129-132$

Romaniuk M.P., Życie, twórczość i posługa Stefana Kardynała Wyszyńskiego Prymasa Tysiqclecia, Warszawa 1994

Sakson A., Od Kłajpedy do Olsztyna. Współcześni mieszkańcy byłych Prus Wschodnich. Kraj Kłajpedzki, Obwód Kaliningradzki, Warmia i Mazury, Poznań 2011

Schwark B., Ihr Name lebt. Ermländische Priester in Leben, Leid und Tod, Osnabrück 1958

Sieński H., Stępień Jan Piotr, [w:] Leksykon Duchowieństwa represjonowanego w PRL w latach 19451989, red. J. Myszor, t. 1, Warszawa 2002, s. 268-270.

Szyfer A., Ludowe zwyczaje, obrzędy, wierzenia i wiedza, [w:] Kultura ludowa Mazurów i Warmiaków, red. J. Burszta, Wrocław 1976, s. 409-415

Szyfer A., Tradycyjne wierzenia i zwyczaje okresu Bożego Narodzenia na Warmii, „Komunikaty Mazursko-Warmińskie", nr 4 (1965), s. 569-580

Szyfer A., Warmiacy: studium tożsamości, Poznań 1996

Śp. Ks. Infułat Wojciech Zink, „Warmińskie Wiadomości Diecezjalne”, nr 2 (1970), s. 53-56 Warmiacy i Mazurzy w PRL. Wybór dokumentów. Rok 1946, oprac. T. Baryła, Olsztyn 1994

Wojtkowski J., Dzieje kapituły warmińskiej 1772-1945, „Studia Warmińskie”, t. XXXII (1995), s. 25-90

Wyszyński S., List Prymasa Polski z 8 XI 1950, „Warmińskie Wiadomości Diecezjalne", nr 5 (1950), s. 2-4 
Wyszyński S., Zapiski więzienne, Paryż 1982

Wyszyński S., Zapiski milenijne. Wybór z dziennika Pro memoria z lat 1965-1967, Warszawa 2001

Zientara Malewska M., Wspomnienia o księdzu prałacie Janie Hanowskim 1873-1968, „Słowo na Warmii i Mazurach", nr 20 (1971)

Żyromski Ż., Przesiedlenia ludności niemieckiej z województw olsztyńskiego poza granice Polski w latach 1945-1950, „Komunikaty Mazursko-Warmińskie", nr 3 (1959) 


\section{Integracyjna działalność Kościoła warmińskiego w pierwszych latach po II wojnie światowej}

Streszczenie: W 1945 r. południowe Prusy Wschodnie, ale bez Królewca, znalazły się w granicach państwa polskiego. Całe dawne dominium warmińskie rządzone do 1772 r.przez biskupów i kapitułę warmińską, kraj katolicki było pod rządami polskimi. W wyniku działań wojennych ziemie wschodniopruskie doznały ogromnych zniszczeń i wyludnienia. Już w 1945 r. w wyniku osadnictwa zmieniał się demograficzny i wyznaniowy obraz tych ziem. Ludność niemiecka została wysiedlona, a ludność mazurska i warmińska odmawiająca przyjęcia polskiego obywatelstwa też musiała te ziemie opuścić. Do 1945 r. katolicy byli jakby diasporą wśród wyznawców ewangelickich. Po 1945 r. wszystko się odwróciło, ludność w większości była katolicka. Kapłani niemieccy ustąpili miejsca duchownym polskim, którzy przyjechali na Warmię i Mazury wraz z polskimi osadnikami. Władze państwowe odmówiły biskupowi warmińskiemu Maksymilianowi Kallerowi kontynuacji rządów biskupich w warmińskiej diecezji. Dr Teodor Bensch został administratorem diecezji. W 1956 r. Tomasz Wilczyński otrzymał nominację na biskupa w Olsztynie, lecz dopiero Józef Drzazga został pełnym ordynariuszem warmińskim po unormowaniu stosunków polsko-niemieckich. Księża katoliccy odegrali niezwykle ważną rolę w procesie zasiedlania ziem, a tym samym integracji ludności. Otwierając kościoły, budowali poczucie stabilizacji, likwidując poczucie tymczasowości. W zmieniającej się politycznej polskiej rzeczywistości Kościół stał się przeciwnikiem władz państwowych. Księża zaczęli doznawać szykan, wypychano Kościół z działalności społecznej. Na Warmii i Mazurach schronienie znalazło wielu żołnierzy podziemia zbrojnego, organizacji politycznych i księży ściganych przez komunistyczne władze. Ze strony tych władz doznawali oni represji. A jednak mimo nieustających szykan nie zmniejszały się wpływy Kościoła, świątynie wciąż były pełne wiernych. Kościół integrował ludzi przybyłych z różnych stron dawnej Polski, obejmował ich opieką nie tylko duszpasterską. Kościół pomagał w odnajdywaniu dawnej świetności Warmii. Na bazie historii tworzył podwaliny zrywania z tymczasowością i pomagał mieszkańcom w procesach zakorzeniania się na nowej ziemi.

\section{The role of the Warmian Church in regional integration in the first years after the Second World War}

Abstract: In 1945 the south of East Prussia, albeit without Königsberg, found itself at the border of the Polish state. The entire former dominion of Warmia was governed until 1772 by bishops and the Warmian Chapter, and it had been a Catholic country governed by Poles. As a result of the events of the war the eastern Prussian territories had experienced immense destruction and depopulation. As early as 1945 the demographic and religious appearance of these territories had changed as a result of settlement. The ethnic German population had been expelled, and those Masurians and Warmians who refused to accept Polish citizens had also had to leave the territories. Until 1945 Catholics had represented a minority within a largely Evangelical society. After 1945 everything was reversed, and the population was majority Catholic. German pastors gave way to Polish priests, who came to Warmia and Masuria alongside the Polish settlers. The state authorities did not agree to 
Warmian bishop Maximillian Kaller continuing in his role as leader of the bishops of the Warmian Diocese. Dr Teodor Bensch became the administrator of the diocese. In 1956 Tomasz Wilczyński received the nomination to become Bishop of Olsztyn, but not until Józef Drzazga became Diocesan Bishop in Warmia after the normalisation of Polish-German relations. Catholic priests played an unusually important role in the process of the settlement of the territories, and at the same time in the integration of the populace. By opening churches, they created a sense of stability, conquering the sense of impermanence. In the changing political reality of Poland, the Church stood counter to the state authorities. Priests started to encounter harassment as the Church was pushed out of the social sphere. In Warmia and Masuria protection was offered to many soldiers of the armed underground, and to political organisations and priests hunted by the communist authorities. These people were oppressed by the authorities. However, despite this unrelenting harassment the influence of the Church was not diminished, and places of worship were full of the faithful. The Church brought together people from all parts of the former Poland and gave them support - not only religious. The Church helped in the rediscovery of the former splendour of Warmia. By invoking history the Church created the springboard for trumping the sense of impermanence and helped residents in their process of setting down roots in this new land.

Słowa kluczowe: Warmia, diecezja warmińska, Kościół katolicki, integracja Key words: Warmia, Diocese of Warmia, Catholic Church, integration 